\title{
Time-cost optimization model proposal for construction projects with genetic algorithm and fuzzy logic approach
}

\author{
Hatice Acar Yildirim \\ Institute of Graduate Studies in Science and Engineering, Istanbul University \\ 34320, Istanbul (Turkey) \\ hatice.acaryildirim@ogr.iu.edu.tr
}

Cemil Akcay (Main and Corresponding Autor)

Istanbul University, Faculty of Architecture

34116, Istanbul (Turkey)

cakcay@istanbul.edu.tr

Manuscript Code: 1465

Date of Acceptance/Reception: 02.12.2019/06.05.2019

DOI: 10.7764/RDLC.18.3.554

\begin{abstract}
Considering the construction industry holds ten percent on average in the gross national product over the world, the importance of efficient use of resources emerges. To alleviate the possibility of the risk factors and various uncertainties' negative impact on the project, the usage of the scheduling tools should be supported for planning as well as risk management. In today's construction perspective, the quality is not a primary objective; construction projects have to be completed within the cost and duration limits. During the construction progress, the inserting of extra activities affects to construction delays. Project success; from the planning stage to the completion of the building, it is possible to plan the resources, use them efficiently, and realize the determined time and cost objectives. In this study, a model is developed by using a fuzzy logic approach and genetic algorithm in order to provide time-cost optimization in construction projects under uncertainties. Firstly, fuzzy sets are used to take into account the effects of time and cost uncertainties on construction works. Fuzzy sets are used to model uncertainties, and the genetic algorithm is used to acquire minimum Project cost and duration. Thus, by establishing a fuzzy time-cost optimization model, optimum time-cost results are obtained according to different risk levels determined by the decision-makers. At the final stage, Pareto fronts from different risk levels that contain both minimum costs and durations are obtained and plotted.
\end{abstract}

Keywords: Construction project, time-cost optimization, genetic algorithm, fuzzy logic.

Introduction

Time and cost analysis are the most important factors for planning and control of construction projects. The selection of different sources and technologies, such as materials, labor force, equipment, and methods, for the realization of an activity, is carried out by construction planners. Uncertainties and risks in construction applications according to the region where the project is implemented are taken into account in this selection process. In this respect, project duration and project cost have been determined according to the technique chosen in the context of regional conditions.

The critical path method (CPM) is used in order to control time and costs in construction project planning as well as to control resources. The trade-off between quality, time, and cost is important in project planning. The most crucial goal of the construction management engineers in project planning is determining the optimum point between time and cost by using trade-off rates. However, in construction works, the costs associated with the duration and duration of work, uncertain variables such as weather conditions, employee productivity, etc. are affected. Methods that take into account the uncertainties in construction and the risks associated with them are being developed (Aminbakhsh, Sönmez, \& Bilir, 2016; Biswasa, Karmakera, \& Biswasa, 2016; Hosseini-Nasab, Pourkheradmand, \& Shahsavaripour, 2017; Zalmai, Akcay, \& Manisali, 2019). The most recent optimization technique developed in recent years is the genetic algorithm method, which is based on the theory of evolution and the principles of natural selection. The genetic Algorithm used for classification, model selection, and other optimization processes; is the most known metaheuristic optimization method applied to discrete time-cost problems ( Sonmez \& Halis, 2012; Aly, 2016).

Since a solution cannot be found with analytical or non-numerical methods for each problem, it is necessary to determine the mathematical expression of the problem. Numerical algorithms such as fuzzy logic have been developed to be used in cases where a problem cannot be expressed mathematically (Agdas, Warne, Osio-Norgaard, \& Masters, 2017). In many studies, fuzzy logic and fuzzy model are used in the time-cost trade-off problem (Eshtehardian, Afshar, \& Abbasnia, 2009; Jebaseeli \& Dhayabaran, 2012; Habibia, Birganib, Koppelaarc, \& Radenovićd, 2018). The genetic 
algorithm is used to determine the minimum costs during the planned project construction period, and the fuzzy logic approach is used to model the uncertainties during the implementation of the work plan with the network programming technique (Akcay, 2003). The mathematical and heuristic models developed for the construction time-cost trade-off solutions are focused on deterministic situations. Non-deterministic methods are rarely taken into account in the timecost trade-off problem.

In this study, the genetic algorithm and fuzzy set theory are used to develop a time-cost trade-off model that considers the uncertainties in construction project activities. The fuzzy set theory has been used to blur the activity time and cost of construction activities, and the genetic algorithm method was used to find optimum time-cost trade-off Pareto results under different uncertainty levels. The goal is to find the most suitable solution on the time and cost of the project performance components under different uncertainty levels.

Description of the Problem

The time-cost trade-off problem is one of the most important concepts of construction management. The objective of this paper is to establish a fuzzy optimal construction time-cost trade-off model. In this context, fuzzy sets were first used in order to take into account the effects of time and cost uncertainties in construction works. Generated fuzzy sets were optimized using a genetic algorithm. Thus, a fuzzy time-cost optimization model was established to achieve optimum time-cost results according to different risk levels determined by decision-makers.

Genetic algorithms are search and optimization tools used in project planning and control. The genetic algorithm helps to identify optimal or near-optimal solutions for problems with large search space (Sorrentino, 2013). GA is also a widely used algorithm for complex problems (Deb, Pratap, Agarwal, \& Meyarivan, 2002). Therefore, the genetic algorithm was chosen as the optimization method in this study.

In the literature, the problem is solved by generally considering the duration and cost of activities as deterministic in time-cost trade-off problems. However, in construction projects, the duration of the operation is uncertain due to external factors such as weather, site congestion, and efficiency level. Accordingly, the operating cost is uncertain. This study presents a new perspective on the problem of time-cost trade-off by taking into account the impact of time and cost uncertainties. In addition, hypothetical applications in time-cost trade-off problems are given in the literature. Within the scope of this study, the model was applied to a real project data, and the results were interpreted with a case study.

State of the Art

The most popular techniques of deterministic time-cost trade-off planning models are analytical and intuitive methods. Linear programming and dynamic programming are two types of mathematical programming methods commonly used to solve time-cost problems (Butcher, 1967; Meyer \& Shaffer, 1965; Talbot, 1982). Mathematical time-cost tradeoff models are only suitable for small-scale projects due to the fact they require large amounts of computation. Heuristic and meta-heuristic models are used in complex and large-scale projects. Feng and Chua proposed models using the genetic algorithm and the Pareto front approach to solve the construction time-cost trade-off problem (Chua, Chan \& Govindan, 1997; Feng, Liu \& Burns, 1997). Many researchers have proposed solutions to time-cost problems using GA (Sonmez \& Halis, 2012; Agdas et al., 2017). However, these studies mainly focused on the deterministic time-cost tradeoff problem.

Since it contains many uncertain variables in construction activities, recently in construction management, it gives importance to non-deterministic scheduling. Classical non-deterministic programming models are PERT and Monte Carlo simulations. These methods are commonly used in practice and mainly based on probability theory (Diaz \& Hadipriono, 1993).

Some researchers have used the fuzzy set theory to model uncertainties about time in project networks (Chanas \& Kamburowski, 1981; McCahon, 1993). In this study, the fuzzy set theory has been used to model the uncertainties of activity time. GA method was used to find optimum time-cost trade-off Pareto results under different risk levels. The following is brief information about the fuzzy set theory and genetic algorithm concepts. 


\section{Fuzzy set theory}

The concept of fuzzy logic was first introduced in 1965 by Prof Lotfi A. Zadeh of the University of California, Berkeley (Akcay, 2003). Fuzzy set theory has been developed for the modeling of verbal expressions that cannot be expressed with mathematical formulas (Klir \& Yuan, 1995). Fuzzy logic applies when the case under consideration is very complex and insufficient information is available, when opinions and values of people are included, or when human judgment and decision-making are needed (Elmas, 2007). Fuzzy sets have degrees in the range [0,1] instead of exact expressions such as 0 and 1. Fuzzy numbers are expressed in different ways, such as triangles and trapezoidal. In this study, the duration and costs of construction activities, which are formed according to different construction techniques, are transferred to the model with the help of fuzzy triangular numbers. Membership function in fuzzy triangular sets is as follows.

$$
\mu(x)=\left\{\begin{array}{cc}
0, & x \leq a \\
\frac{x-a}{b-a}, & a \leq x \leq b \\
\frac{c-x}{c-b}, & b \leq x \leq c \\
0, & c \leq x
\end{array}\right.
$$

As shown in Figure 1, the two basic points and membership degrees of the triangular fuzzy set a and c are 0 , and point b is central, and the degree of membership is 1 (Haque \& Hasin, 2012).

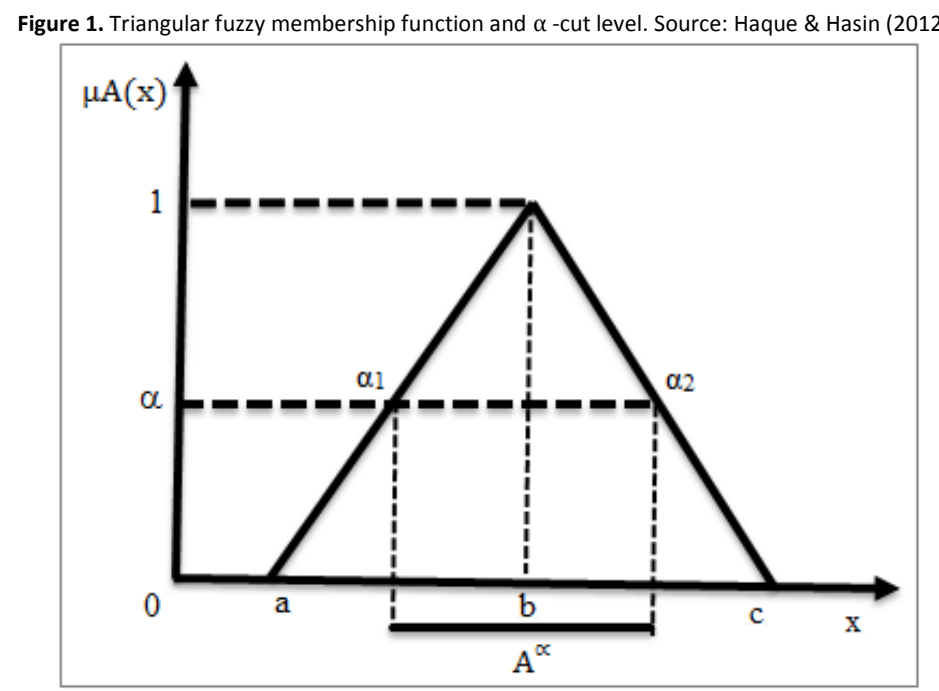

$A$ set contains all elements of $\mathrm{X}$ that are equal to or greater than the special value $\alpha$.

$A_{\alpha}=\left\{x \in X: \mu_{A}(x) \geq \alpha\right\}$

Increasing the membership rating from 0 to 1 narrows the confidence interval. Thus, the number $b$ is closer. Confidence interval at any $\alpha$ level $[\alpha 1, \alpha 2]$; while $\alpha=0$ [a, c]; If $\alpha=1$, it is [b, b]. In this study, the optimal solution set at different $\alpha$ levels will be found according to uncertainty and risk situation in time-cost modeling with triangular fuzzy sets.

In this study, fuzzy sets were used to model both uncertainty levels and to obtain an optimistic and pessimistic point of view for both optimum cost and duration calculations. The initial-generation of fuzzy sets needs to a subjective expert opinion. To model the variance of uncertainty levels, different levels of alpha cuts were used. The optimistic and pessimistic points of view took a role in the defuzzification process. An optimistic point of view needs first of the maxima defuzzification rule. On the other hand, to obtain outputs of a pessimistic point of view, we used the Last of Maxima rule.

\section{Genetic algorithms}

A genetic algorithm is an intuitive search approach that enables the optimization of complex and difficult problems. This procedure is based on the principle of survival of the strong through some operators mimicking nature (Goldberg \& Holland, 1988). 
Genetic algorithms have many advantages over conventional optimization algorithms, and the most remarkable advantage is that it can provide optimal solutions to complex optimization problems. Genetic algorithms can address various types of optimization of the suitability function, such as stationary or non-stationary, linear or nonlinear, continuous, or discrete. Since generations in a population act as independent agents, the population (or any subgroup) can simultaneously explore the search area in many ways. The genetic algorithm is used to solve many optimization problems as well as the optimization of construction network diagrams (Chua et al., 1997; Feng, Liu \& Burns, 1997).

A genetic algorithm is a meta-heuristic approach consisting of natural selection and natural genetics-dependent search techniques. The possible set of solutions in the genetic algorithm consists of populations of chromosomes. New chromosomes occur when two chromosomes are crossed over or mutated. The characteristics of the parent chromosome pair selected according to fitness value are transferred to the new population as a result of reproduction. Crossover or mutation that creates new individuals from the present population is the main distinguishing feature of genetic algorithms. In cases where the new generation chromosomes are the same, termination may be applied. The resulting chromosomes are expected to give the optimum set of time-cost populations in the model.

Genetic algorithms, which are successful in solving complex problems, have three basic genetic processes: reproduction, crossover, and mutation. The differentiation of the new generation from the previous generation is achieved by transferring the good features of the chromosomes compatible with these three processes to the new population. With each differentiating generation, solutions can be searched for at different points in the solution space (Paksoy \& Uzun, 2015). Genetic operators need to be applied to obtain more suitable chromosomes from appropriate chromosomes in the population (Mori \& Tseng, 1997).

In this study, crossover and mutation operators were used to obtain new generation chromosomes by using time and cost chromosomes. One cut point crossover and uniform mutation operators were used in the model. As shown in Figure 2, a cut-off point is selected in the parent strings, and different parts of the two-parent strings are modified to yield new generation chromosomes. In mutation, one or more genes are changed on a chromosome.

Figure 2. One-point crossover and uniform mutation operators. Source: Leu, Chen, \& Yang (2001)

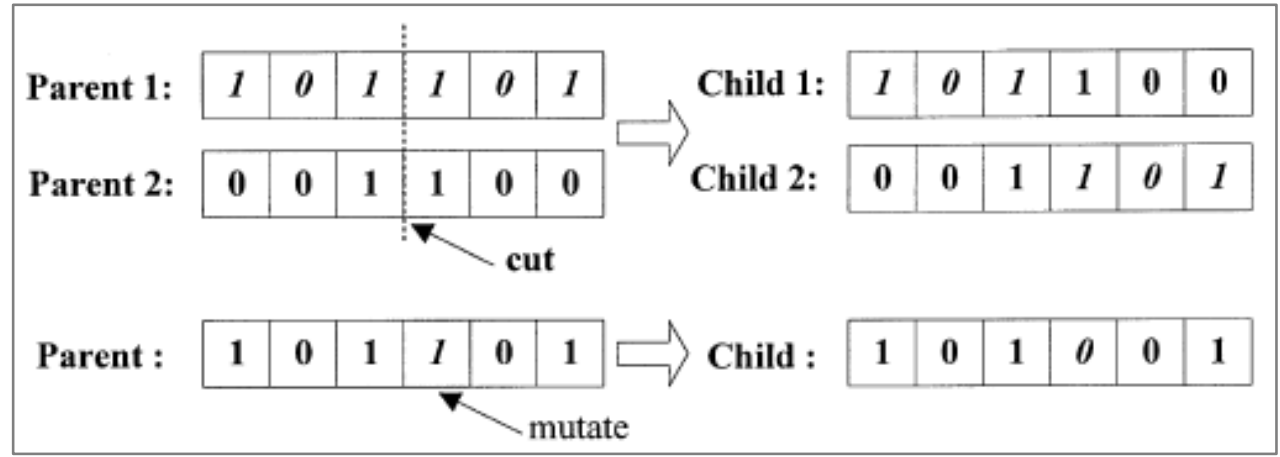

The general parameters used in time-cost trade-off optimization formulations are discussed in this section. The purpose of the genetic algorithm-based fuzzy time-cost trade-off model is to minimize the cost of the project within a given project period (Leu et al., 2001). The proposed model consists of four subunits.

\section{Activity time and cost creation unit}

This unit constitutes the possible duration of an activity. Each character of the chromosome indicates the duration of the activity. The character value is limited between the compressed and delayed values according to the risk level. Activity periods are divided into three groups the compressed time, normal time, and delayed time. Each option period (compressed, normal, and delayed times) is blurred with a triangular fuzzy function (Figure 3a). The center of gravity, which is a fuzzy inference system, is used to determine the duration and cost of action at any level of risk. (Figure 4).

When the center of gravity method is applied to the triangular fuzzy cluster, the center of gravity $\left(\mathrm{G}_{\mathrm{x}}\right)$ of the trapezoid area under the $\alpha$-segment indicates the time or cost value in the and-segment (Eq. 1). 


$$
G_{x}=\frac{\sum X_{i} \cdot A_{i}}{\sum A_{i}}=\frac{X_{1} \cdot A_{1}+X_{2} \cdot A_{2}+X_{3} \cdot A_{3}}{A_{1}+A_{2}+A_{3}}
$$

Figure 3. (a) Fuzzy activity time, (b) Fuzzy activity cost. Source: Sen (2009)

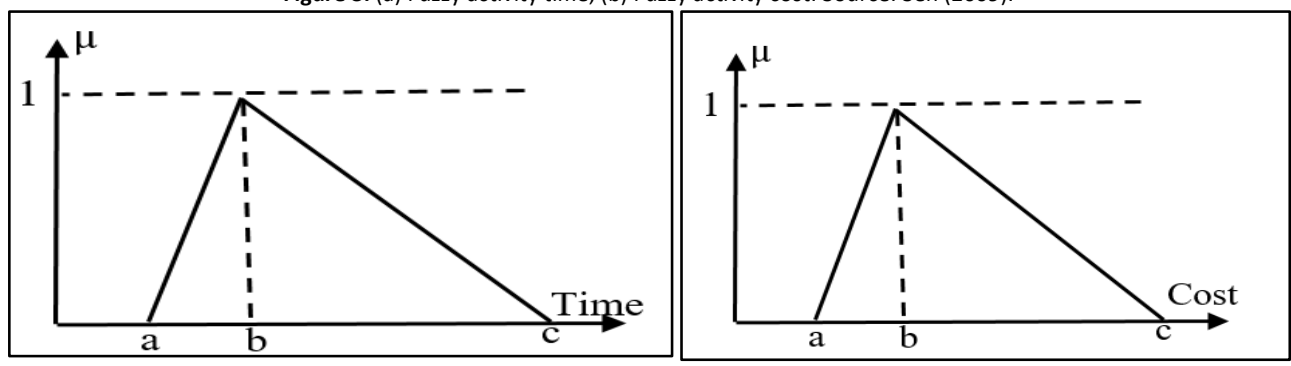

Figure 4. Center of gravity method. Source: Sen (2009).

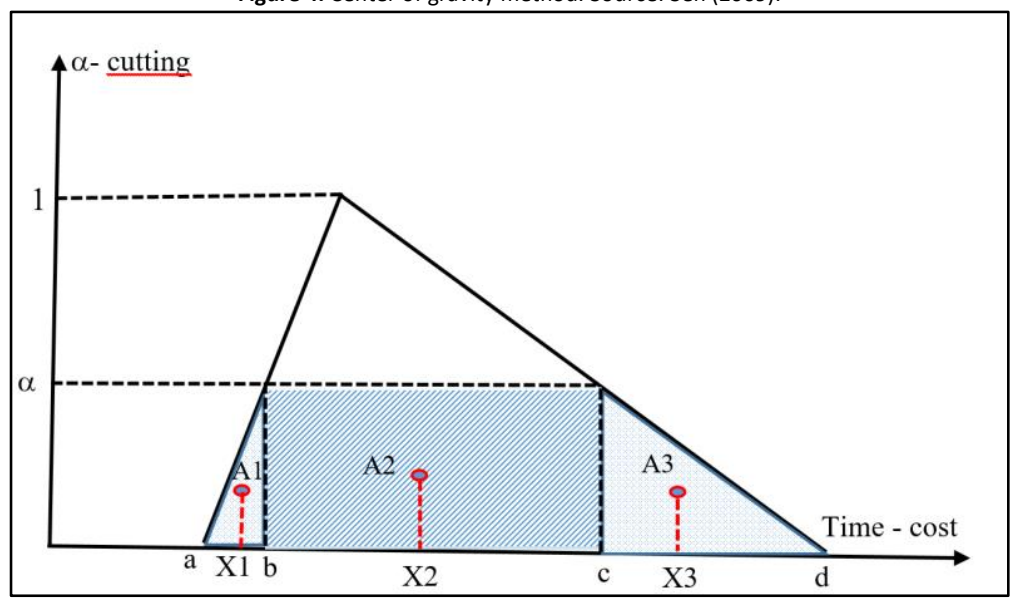

\section{Project duration and project cost calculation unit}

CPM calculations are made with the help of graph method for project duration and costs and provide suitable options to deal with large-size projects (Agdas et al., 2017).

\section{Project time-cost trade-off unit}

In genetic algorithm optimization, the activity duration combination is required that gives the optimum solution. Minimum project duration and costs are two main objectives to be searched during the genetic algorithm process (Feng, Liu \& Burns, 1997). Crossover and mutation operators two simple operators that serve for generating different solution alternatives. New chromosomes are selected for crossover operation for constituting the next generation according to the Roulette wheel principle. The mutation operation updates individual genes in the chromosome to provide variety in the population (Goldberg \& Holland, 1988).

\section{Output unit}

Using Pareto solutions to obtain optimum or near-optimum results at the end of the time-cost trade-off unit, for different risk levels suitable alternative project duration- cost pairs had been found. The expert/decision-maker evaluates the Pareto results and selects the construction method that gives the appropriate time-cost option. The mathematical expression used for this method is given in Eqs. 2-4. The total fuzzy cost of the project in Eq. 2 may be calculated, and the completion of the project within the required period is restricted in Eq. 3. Eq. 4 limits the duration of activity to the minimum compressed time to the maximum normal time (Haque \& Hasin, 2012). Figure 5 shows the flow diagram of the model.

$$
\begin{gathered}
\min C^{\propto}=\sum_{\forall i}\left(C^{\propto}{ }_{N_{i}}+C^{\propto}{ }_{C_{i}}+C^{\propto}{ }_{J_{i}}\right) \\
C^{\propto}{ }_{N_{i}}=d^{\propto}{ }_{i} \times N^{\propto}{ }_{i} \\
C^{\propto}{ }_{C_{i}}=\max \left(d^{\propto}{ }_{i_{\text {low }}}-d^{\propto}{ }_{i}, 0\right) \times N^{\alpha}{ }_{C_{i}}
\end{gathered}
$$




$$
\begin{gathered}
\mathrm{C}_{\mathrm{J}_{\mathrm{i}}}^{\alpha}=\mathrm{d}^{\alpha}{ }_{\mathrm{i}} \times \mathrm{N}^{\alpha}{ }_{\mathrm{J}_{\mathrm{i}}} \\
\mathrm{T}^{\alpha} \leq \mathrm{D} \\
\mathrm{d}^{\alpha}{ }_{\mathrm{i}_{\text {min }}} \leq \mathrm{d}^{\alpha}{ }_{\mathrm{i}} \leq \mathrm{d}^{\alpha}{ }_{\mathrm{i}_{\text {max }}}
\end{gathered}
$$

Where:

$\mathrm{C}^{\propto}$ : Total Project cost at a specific $\alpha$-cut level

$\mathrm{d}^{\propto}{ }_{\mathrm{i}}$ : Duration of activity $\mathrm{i}$ at a specific $\alpha$-cut level

$\mathrm{C}^{\propto}{ }_{\mathrm{N}_{\mathrm{i}}}$ : Normal cost of activity $\mathrm{i}$ at the duration $\mathrm{d}^{\propto}{ }_{\mathrm{i}}$

$\mathrm{C}^{\propto}{ }_{\mathrm{C}_{\mathrm{i}}}$ : Crash cost of activity $\mathrm{i}$ at the duration $\mathrm{d}^{\propto}{ }_{\mathrm{i}}$

$\mathrm{C}^{\propto}{ }_{\mathrm{J}_{\mathrm{i}}}$ : Indirect cost of activity $\mathrm{i}$ at the duration $\mathrm{d}^{\propto}{ }_{\mathrm{i}}$

$\mathrm{N}^{\propto}{ }_{i}$ : Normal cost rate of activity $i$ at the duration $d^{\propto}{ }_{i}$

$\mathrm{N}^{\propto}{ }_{\mathrm{C}_{\mathrm{i}}}$ : Crash cost rate of activity $\mathrm{i}$ at the duration $\mathrm{d}^{\propto}{ }_{\mathrm{i}}$

$\mathrm{N}^{\propto}{ }_{\mathrm{J}_{\mathrm{i}}}$ : Indirect cost rate of activity $\mathrm{i}$ at the duration $\mathrm{d}^{\propto}{ }_{\mathrm{i}}$

$\mathrm{T}^{\propto}$ : Project duration at a specific a-cut level

D: Permissible maximum project duration

$\mathrm{d}^{\alpha}{ }_{\mathrm{i}_{\text {low }}}$ : Minimum duration of activity $\mathrm{i}$ at a specific a-cut level finished normally

$\mathrm{d}^{\propto}{ }_{\mathrm{i}_{\min }}$ : Minimum duration of activity $\mathrm{i}$ at a specific a-cut level finished in crash

$\mathrm{d}^{\propto}{ }_{\mathrm{i}_{\text {max }}}$ : Maximum duration of activity $\mathrm{i}$ at a specific a-cut level finished normally

Figure 5. The flow chart of the developed model. Source: Acar Yıldırım (2018).

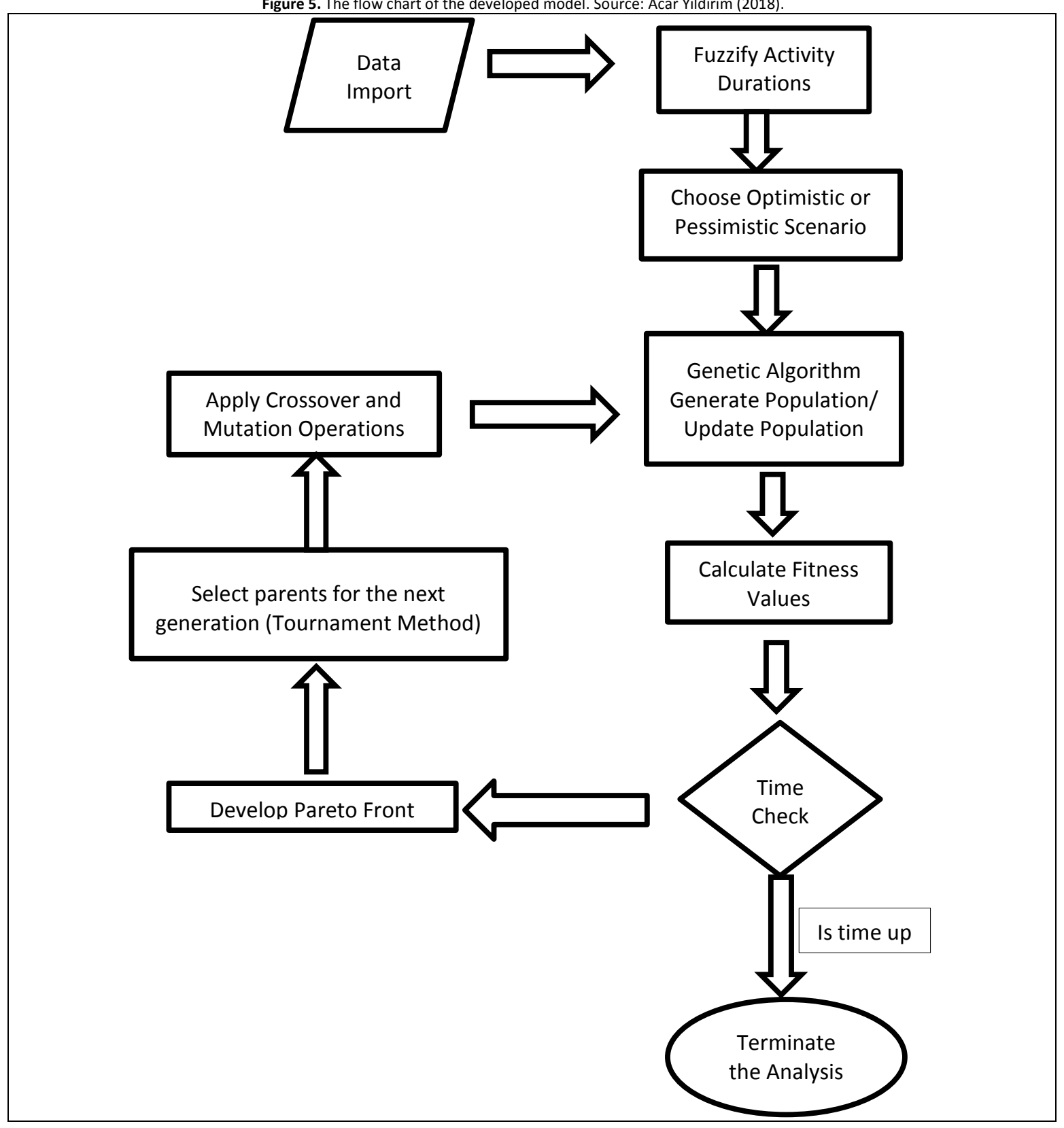


The results obtained by applying on a real construction project data were evaluated in the prepared model. In the application study, the concrete and roofing production sections on the terrace and seating roofs, which are located in two different elevations in the same building, were taken into consideration (Figure 6).

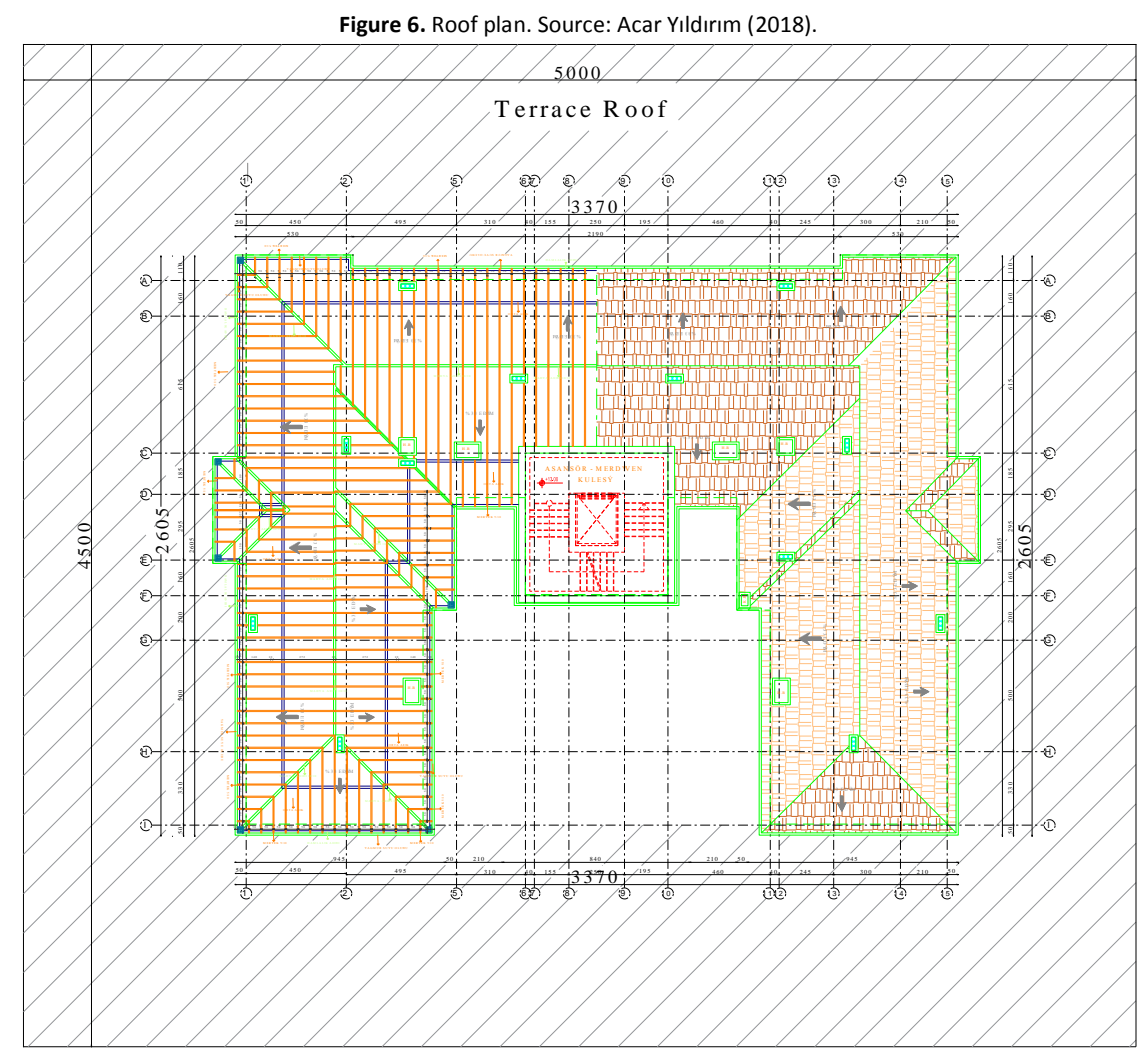

Firstly, the construction work items of the project were determined, and the relations between the activities were defined. The CPM network of the project has been drawn according to the below (1-5) assumptions, and the quantities of the activities to be performed have been extracted.

1. Each activity has a similar time-cost relationship.

2. The activities are carried out by the main contractor or by the subcontractor with the unit price contract.

3. Normal and compressed cost values are clearly known.

4. Activity periods are fuzzy due to environmental factors. Blurring was performed based on triangular fuzzy numbers, which is based on normal and compressed times and costs.

5. The relations between the activities are the finish to start. After an activity ends, the next activity begins.

In the first stage of the project, roofing works were done according to the technical specifications. The roof works were carried out by taking into consideration the occupational health and safety, and the terrace works were carried out in parallel. The CPM network diagram of the project is shown in Figure 7.

Figure 7. CPM arrow type network diagram of application project. Source: Acar Yıldırım (2018).

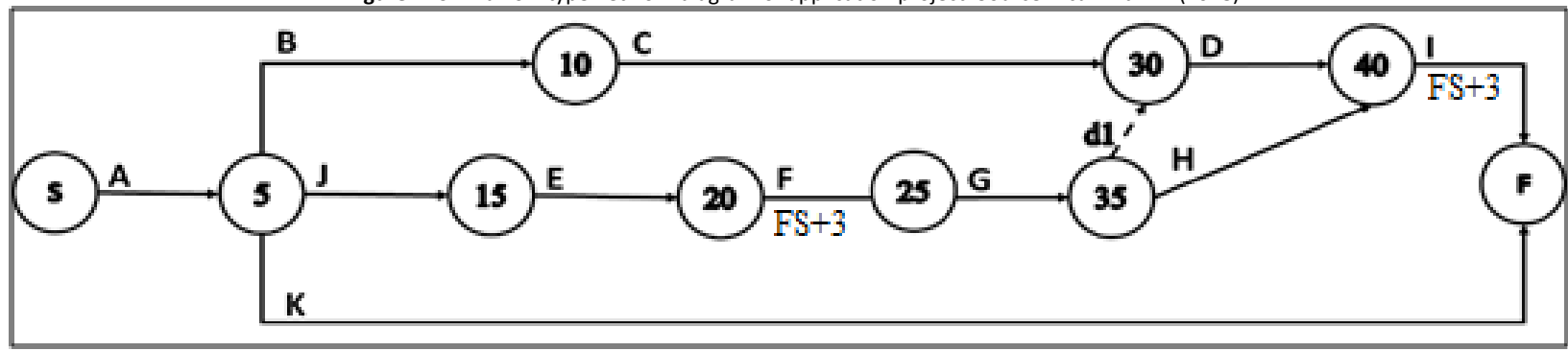


Fuzzy time-cost pairs were calculated on the basis of different risk levels in the project. The best time-cost pairs were then obtained by the genetic algorithm optimization model. Table 1 shows the determined time and costs of the work items with different materials and workmanship.

Table 1. Estimated time-cost of the activities. Source: Acar Yıldırım (2018).

\begin{tabular}{|c|c|c|c|c|c|c|c|c|c|}
\hline ID & Activity & Option & Pose [14] & $\begin{array}{l}\text { Quantities } \\
\text { (m2) }\end{array}$ & $\begin{array}{l}\text { Unit } \\
\text { cost } \\
\text { (USD) }\end{array}$ & $\begin{array}{c}\text { Estimated } \\
\text { cost } \\
\text { (USD) }\end{array}$ & $\begin{array}{l}\text { Activity } \\
\text { rate }(\mathrm{h})\end{array}$ & $\begin{array}{l}\text { Construction } \\
\text { duration (h) }\end{array}$ & $\begin{array}{l}\text { Approximate } \\
\text { duration } \\
\text { (day) }\end{array}$ \\
\hline \multirow[t]{2}{*}{ A } & \multirow{2}{*}{$\begin{array}{l}\text { Wood free- } \\
\text { standing roof }\end{array}$} & 1 & Y.21.101/01 & 650 & 23.0 & 14950 & 0.28 & 182 & 23 \\
\hline & & 2 & Y.21.101/02 & 650 & 22.2 & 14430 & 0.26 & 169 & 22 \\
\hline B & $\begin{array}{l}\text { Heat insulation } \\
\text { in Roof }\end{array}$ & 1 & Y.19.061/001 & 715 & 3.3 & 2360 & 0.30 & 214.5 & 27 \\
\hline \multirow[t]{3}{*}{ C } & \multirow{3}{*}{$\begin{array}{l}\text { Waterproofing } \\
\text { in Roof }\end{array}$} & 1 & $18.246 / 1$ & 715 & 2.8 & 2002 & 0.20 & 143 & 18 \\
\hline & & 2 & $18.246 / 2$ & 715 & 3.2 & 2288 & 0.20 & 143 & 18 \\
\hline & & 3 & Y.18.245/006 & 715 & 5.1 & 3647 & 0.30 & 214.5 & 27 \\
\hline \multirow[t]{4}{*}{ D } & \multirow[t]{4}{*}{ Roofing } & 1 & 18.232 & 715 & 29.3 & 20950 & 1.42 & 1015.3 & 127 \\
\hline & & 2 & $18.233 / 1$ & 715 & 25.8 & 18447 & 1.23 & 879.5 & 110 \\
\hline & & 3 & Y.18.201/A102 & 715 & 25.5 & 18233 & 1.00 & 715.0 & 90 \\
\hline & & 4 & Y.18.201/A105 & 715 & 15.0 & 10725 & 1.10 & 786.5 & 99 \\
\hline$E$ & $\begin{array}{c}\text { Leveling } \\
\text { concrete in the } \\
\text { terrace }\end{array}$ & 1 & Y.27.581 & 1600 & 3.7 & 5920 & 0.45 & 720 & 90 \\
\hline \multirow[t]{3}{*}{$\mathrm{F}$} & \multirow{3}{*}{$\begin{array}{l}\text { Waterproofing } \\
\text { in terrace }\end{array}$} & 1 & $18.465 / 2$ & 1600 & 10.3 & 16480 & 0.50 & 800 & 100 \\
\hline & & 2 & $18.468 / 2$ & 1600 & 8.9 & 14240 & 0.50 & 800 & 100 \\
\hline & & 3 & Y.19.085/027 & 1600 & 7.4 & 11840 & 0.60 & 960 & 120 \\
\hline \multirow[t]{2}{*}{ G } & \multirow{2}{*}{$\begin{array}{l}\text { Heat insulation } \\
\text { in terrace }\end{array}$} & 1 & 19.057 & 1600 & 3.5 & 5600 & 0.06 & 96 & 12 \\
\hline & & 2 & $19.048 / 9$ & 1600 & 3.3 & 5280 & 0.25 & 400 & 50 \\
\hline $\mathrm{H}$ & $\begin{array}{c}\text { Screed concrete } \\
\text { for insulation in } \\
\text { terrace }\end{array}$ & 1 & 19.101/MK & 1600 & 9.3 & 14880 & 1.16 & 1856 & 232 \\
\hline \multirow[t]{4}{*}{1} & \multirow[t]{4}{*}{ Terrace covering } & 1 & $26.007 / 145 \mathrm{~A}$ & 1600 & 11.9 & 19040 & 0.45 & 720 & 90 \\
\hline & & 2 & 26.211/MK & 1600 & 37.2 & 59520 & 0.76 & 1220 & 153 \\
\hline & & 3 & Y.26.020/003A & 1600 & 34.4 & 55040 & 0.75 & 1200 & 150 \\
\hline & & 4 & Y.26.020/103A & 1600 & 39.7 & 63520 & 0.77 & 1237.3 & 155 \\
\hline \multirow[t]{3}{*}{ J } & \multirow[t]{3}{*}{ Parapet } & 1 & 26.752 & 60 & 42.9 & 2574 & 1.30 & 78.2 & 10 \\
\hline & & 2 & Y.26.020/051A & 60 & 48.6 & 2916 & 4.59 & 275.4 & 35 \\
\hline & & 3 & Y.26.020/151A & 60 & 53.3 & 3198 & 4.59 & 275.4 & 35 \\
\hline \multirow[t]{2}{*}{ K } & \multirow{2}{*}{$\begin{array}{l}\text { Concealed } \\
\text { gutter }\end{array}$} & 1 & 24.052 & 150 & 32.6 & 4890 & 1.15 & 172.5 & 22 \\
\hline & & 2 & 24.053 & 150 & 32.3 & 4845 & 1.20 & 180.0 & 23 \\
\hline
\end{tabular}

In the first phase, the average daily production amounts of a team were calculated for all alternative poses of all activities. For this purpose, the team speeds of the related poses with the help of the analysis tables of the respective poses were calculated. Afterward, considering the daily working hours of the team, the average production amount that a team can make per unit time is determined. Table 2 shows the normal, compressed, and delayed time and costs.

Different construction techniques and different completion times have been determined for the activities planned to be carried out in the implementation project, and options have been established. Compressed, normal, and delayed time and costs are blurred with the help of fuzzy triangular numbers (Figures 8 and 9). 


\begin{tabular}{|c|c|c|c|c|c|c|c|c|c|c|}
\hline ID & Activity & Option & Pose [14] & $\begin{array}{c}\text { Team } \\
\text { (person) }\end{array}$ & $\begin{array}{l}\text { Time } \\
\text { (day) }\end{array}$ & $\begin{array}{c}\text { Normal } \\
\text { Daily running } \\
\text { cost } \\
\text { (workmanship) } \\
\text { (USD) }\end{array}$ & $\begin{array}{l}\text { Time } \\
\text { (day) }\end{array}$ & $\begin{array}{l}\text { Compressed } \\
\text { Daily running } \\
\text { cost } \\
\text { (workmanship) } \\
\text { (USD) }\end{array}$ & $\begin{array}{l}\text { Time } \\
\text { (day) }\end{array}$ & $\begin{array}{c}\text { Delayed } \\
\text { Daily running } \\
\text { cost } \\
\text { (workmanship) } \\
\text { (USD) }\end{array}$ \\
\hline \multirow[t]{2}{*}{ A } & \multirow{2}{*}{$\begin{array}{l}\text { Wood } \\
\text { free- } \\
\text { standing } \\
\text { roof }\end{array}$} & 1 & Y.21.101/01 & 3 & 7 & 263.8 & 6 & 335.7 & 8 & 191.8 \\
\hline & & 2 & Y.21.101/02 & 3 & 6 & 284.1 & 5 & 361.5 & 7 & 206.6 \\
\hline B & $\begin{array}{c}\text { Heat } \\
\text { insulation } \\
\text { in Roof }\end{array}$ & 1 & Y.19.061/001 & 5 & 7 & 31.8 & 6 & 40.5 & 6 & 23.2 \\
\hline \multirow[t]{3}{*}{ C } & \multirow{3}{*}{$\begin{array}{l}\text { Waterproo } \\
\text { fing in Roof }\end{array}$} & 1 & $18.246 / 1$ & 2 & 8 & 52.6 & 7 & 67.0 & 9 & 38.3 \\
\hline & & 2 & $18.246 / 2$ & 2 & 8 & 52.6 & 7 & 67.0 & 9 & 38.3 \\
\hline & & 3 & Y.18.245/006 & 4 & 6 & 77.6 & 5 & 98.8 & 7 & 56.5 \\
\hline \multirow[t]{4}{*}{ D } & \multirow[t]{4}{*}{ Roofing } & 1 & 18.232 & 5 & 21 & 113.5 & 17 & 144.5 & 26 & 82.6 \\
\hline & & 2 & $18.233 / 1$ & 5 & 18 & 151.3 & 15 & 192.6 & 22 & 110.0 \\
\hline & & 3 & Y.18.201/A102 & 6 & 12 & 81.3 & 10 & 103.44 & 15 & 59.1 \\
\hline & & 4 & Y.18.201/A105 & 5 & 16 & 67.1 & 14 & 85.5 & 20 & 48.8 \\
\hline $\mathrm{E}$ & $\begin{array}{l}\text { Leveling } \\
\text { concrete in } \\
\text { terrace }\end{array}$ & 1 & Y.27.581 & 6 & 12 & 75.1 & 10 & 95.6 & 15 & 54.7 \\
\hline \multirow[t]{3}{*}{$\mathrm{F}$} & \multirow{3}{*}{$\begin{array}{l}\text { Waterproo } \\
\text { fing in } \\
\text { terrace }\end{array}$} & 1 & $18.465 / 2$ & 6 & 14 & 72.0 & 12 & 91.7 & 17 & 52.4 \\
\hline & & 2 & $18.468 / 2$ & 6 & 14 & 72.0 & 12 & 91.7 & 17 & 52.4 \\
\hline & & 3 & Ү.19.085/027 & 6 & 16 & 77.7 & 14 & 98.9 & 20 & 56.5 \\
\hline \multirow[t]{2}{*}{ G } & \multirow{2}{*}{$\begin{array}{l}\text { Heat } \\
\text { insulation } \\
\text { in the } \\
\text { terrace }\end{array}$} & 1 & 19.057 & 1 & 10 & 83.3 & 9 & 106 & 11 & 60.6 \\
\hline & & 2 & $19.048 / 9$ & 3 & 14 & 73.9 & 12 & 94.1 & 17 & 53.8 \\
\hline $\mathrm{H}$ & $\begin{array}{l}\text { Screed } \\
\text { concrete } \\
\text { for } \\
\text { insulation } \\
\text { in the } \\
\text { terrace }\end{array}$ & 1 & 19.101/MK & 5 & 35 & 75.3 & 31 & 95.9 & 40 & 54.8 \\
\hline \multirow[t]{4}{*}{1} & \multirow{4}{*}{$\begin{array}{l}\text { Terrace } \\
\text { covering }\end{array}$} & 1 & $26.007 / 145 \mathrm{~A}$ & 5 & 15 & 216.4 & 12 & 273.4 & 18 & 157.4 \\
\hline & & 2 & $26.211 / \mathrm{MK}$ & 5 & 25 & 302.5 & 21 & 385.0 & 31 & 220.0 \\
\hline & & 3 & Y.26.020/003A & 5 & 24 & 223.6 & 20 & 284.6 & 30 & 162.6 \\
\hline & & 4 & Y.26.020/103A & 5 & 25 & 216.9 & 21 & 276 & 31 & 157.7 \\
\hline \multirow[t]{3}{*}{ J } & \multirow[t]{3}{*}{ Parapet } & 1 & 26.752 & 2 & 4 & 231.0 & 4 & 294.0 & 5 & 168.0 \\
\hline & & 2 & Y.26.020/051A & 3 & 9 & 74.8 & 8 & 95.3 & 11 & 54.4 \\
\hline & & 3 & Y.26.020/151A & 3 & 9 & 74.8 & 8 & 95.3 & 11 & 54.4 \\
\hline \multirow[t]{2}{*}{ K } & \multirow{2}{*}{$\begin{array}{l}\text { Concealed } \\
\text { gutter }\end{array}$} & 1 & 24.052 & 4 & 9 & 140.0 & 8 & 178.2 & 6 & 101.9 \\
\hline & & 2 & 24.053 & 4 & 6 & 73.9 & 5 & 94.0 & 6 & 53.7 \\
\hline
\end{tabular}

Indirect cost: USD 85.7/Day. 

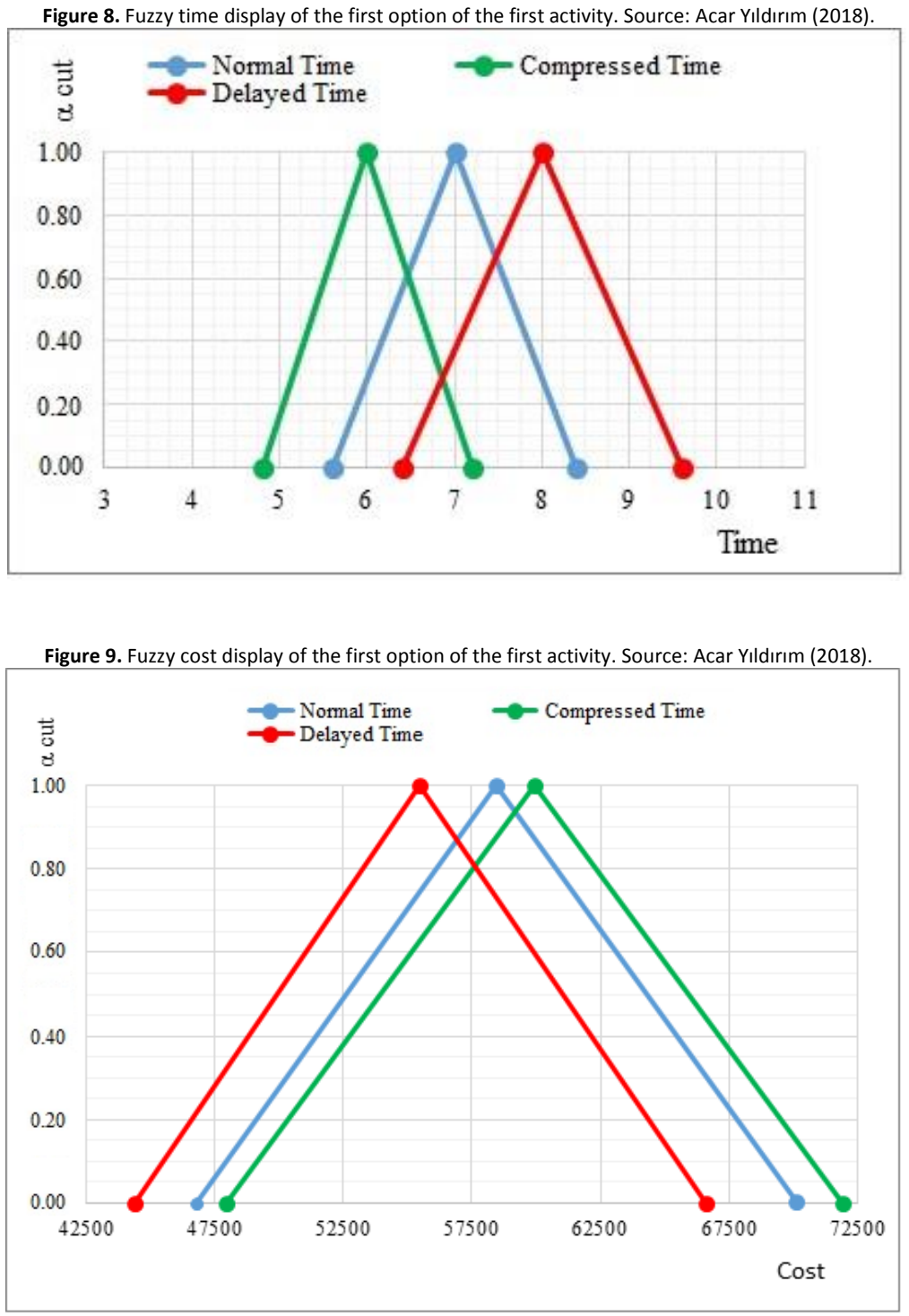

CPM solutions were obtained according to different risk levels with the help of a genetic algorithm in the population consisting of time-cost pairs of the blurred activity. The solutions were evaluated by the Pareto method, and optimum "project duration-project cost yöntem solution was sought. Each "project duration-project cost" solution selected within optimum results determines the activity options to be used in project construction.

Results and discussion

The optimal solution for project time-cost trade-off was sought in the search with a genetic algorithm in fuzzy time-cost sets. The solution search was achieved by generating 1000 populations. The solutions were evaluated according to the Pareto method. An average of 120 generations was generated at each risk level by genetic algorithm. An average of 58 Pareto results emerged at each risk level. Tables 3 and 4 provide minimum and maximum project time cost values at different risk levels, while Figure 10 gives options based on different risk levels.

When the results of the problem (given in Figure 10-a) are examined, it is seen that the optimistic results are below the normal result curve. In the project process, as the level of alpha cuts increases in optimistic conditions, uncertainties, and risks decrease for the same period, and project cost increases. It is observed that the project will be completed below the normal costs and will be completed in a shorter time when worked closely with the optimistic limits. 
Table 3. Analysis results for optimistic project time-cost values for different risk levels.

\begin{tabular}{|c|c|c|c|c|c|c|c|c|c|c|c|c|c|c|c|}
\hline \multirow{2}{*}{$\begin{array}{l}\text { Solution } \\
\text { set }\end{array}$} & \multirow[b]{2}{*}{ Alpha cut } & \multirow{2}{*}{$\begin{array}{l}\text { Time } \\
\text { (day) }\end{array}$} & \multirow{2}{*}{$\begin{array}{l}\text { R-time } \\
\text { (day) }\end{array}$} & \multirow[b]{2}{*}{ Cost (USD) } & \multicolumn{11}{|c|}{ Activity options } \\
\hline & & & & & A & B & C & $\mathrm{D}$ & $E$ & $\mathrm{~F}$ & $\mathrm{G}$ & $\mathrm{H}$ & 1 & $\mathrm{~J}$ & $\mathrm{~K}$ \\
\hline & F-Alfa 0.2 & 44.6 & 45 & 138679 & 2 & 3 & 3 & 11 & 2 & 5 & 2 & 2 & 5 & 5 & 3 \\
\hline & F-Alfa 0.4 & 46.5 & 47 & 142982 & 2 & 3 & 3 & 11 & 2 & 5 & 2 & 2 & 8 & 8 & 2 \\
\hline \multirow[t]{3}{*}{ Optimist } & F-Alfa 0.5 & 47.4 & 48 & 145181 & 2 & 3 & 4 & 10 & 2 & 5 & 2 & 2 & 8 & 5 & 3 \\
\hline & F-Alfa 0.6 & 48.8 & 49 & 147839 & 2 & 3 & 3 & 10 & 2 & 5 & 2 & 2 & 8 & 5 & 3 \\
\hline & F-Alfa 0.8 & 50.9 & 51 & 154267 & 2 & 3 & 3 & 10 & 2 & 5 & 2 & 2 & 8 & 5 & 3 \\
\hline \multirow[t]{3}{*}{ Normal } & Alfa 1.0 & 52.0 & 52 & 161169 & 2 & 3 & 3 & 11 & 2 & 5 & 2 & 2 & 8 & 5 & 4 \\
\hline & L-Alfa 0.8 & 53.8 & 54 & 168555 & 2 & 2 & 6 & 11 & 2 & 5 & 2 & 2 & 8 & 5 & 3 \\
\hline & L-Alfa 0.6 & 55.7 & 56 & 178995 & 2 & 3 & 4 & 10 & 2 & 5 & 2 & 2 & 5 & 5 & 4 \\
\hline \multirow[t]{3}{*}{ Pessimist } & L-Alfa 0.5 & 56.6 & 57 & 181374 & 2 & 3 & 3 & 11 & 2 & 5 & 2 & 2 & 5 & 5 & 6 \\
\hline & L-Alfa 0.4 & 57.5 & 58 & 180670 & 2 & 3 & 4 & 10 & 2 & 5 & 2 & 2 & 8 & 5 & 3 \\
\hline & L-Alfa 0.2 & 59.4 & 60 & 186667 & 2 & 3 & 3 & 11 & 2 & 5 & 2 & 2 & 8 & 5 & 3 \\
\hline
\end{tabular}

\begin{tabular}{|c|c|c|c|c|c|c|c|c|c|c|c|c|c|c|c|}
\hline \multirow{2}{*}{$\begin{array}{l}\text { Solution } \\
\text { set }\end{array}$} & \multirow[b]{2}{*}{ Alpha cut } & \multirow{2}{*}{$\begin{array}{l}\text { Time } \\
\text { (day) }\end{array}$} & \multirow{2}{*}{$\begin{array}{l}\text { R-time } \\
\text { (day) }\end{array}$} & \multirow{2}{*}{$\begin{array}{l}\text { Cost } \\
\text { (USD) }\end{array}$} & \multicolumn{11}{|c|}{ Activity options } \\
\hline & & & & & A & $\mathrm{B}$ & C & $\mathrm{D}$ & $E$ & $\mathrm{~F}$ & G & $\mathrm{H}$ & 1 & $\mathrm{~J}$ & $\mathrm{~K}$ \\
\hline \multirow[t]{5}{*}{ Optimist } & F-Alfa 0.2 & 97.6 & 98 & 100541 & 3 & 3 & 3 & 12 & 3 & 9 & 3 & 3 & 3 & 6 & 6 \\
\hline & F-Alfa 0.4 & 101.9 & 102 & 105512 & 3 & 3 & 3 & 12 & 3 & 9 & 3 & 3 & 3 & 6 & 3 \\
\hline & F-Alfa 0.5 & 104.1 & 105 & 107723 & 3 & 3 & 3 & 12 & 3 & 9 & 3 & 3 & 3 & 6 & 6 \\
\hline & F-Alfa 0.6 & 106.3 & 107 & 110117 & 3 & 3 & 3 & 12 & 3 & 9 & 3 & 3 & 3 & 6 & 6 \\
\hline & F-Alfa 0.8 & 110.6 & 111 & 114904 & 3 & 3 & 3 & 12 & 3 & 9 & 3 & 3 & 3 & 6 & 6 \\
\hline Normal & Alfa 1.0 & 115.0 & 115 & 119692 & 3 & 3 & 3 & 12 & 3 & 9 & 3 & 3 & 3 & 6 & 6 \\
\hline \multirow[t]{5}{*}{ Pessimist } & L-Alfa 0.8 & 119.4 & 120 & 124480 & 3 & 3 & 3 & 12 & 3 & 9 & 3 & 3 & 3 & 6 & 6 \\
\hline & L-Alfa 0.6 & 123.7 & 124 & 129267 & 3 & 3 & 3 & 12 & 3 & 9 & 3 & 3 & 3 & 6 & 6 \\
\hline & L-Alfa 0.5 & 125.9 & 126 & 131661 & 3 & 3 & 3 & 12 & 3 & 9 & 3 & 3 & 3 & 6 & 6 \\
\hline & L-Alfa 0.4 & 128.1 & 129 & 134055 & 3 & 3 & 3 & 12 & 3 & 9 & 3 & 3 & 3 & 6 & 6 \\
\hline & L-Alfa 0.2 & 132.4 & 133 & 138843 & 3 & 3 & 3 & 12 & 3 & 9 & 3 & 3 & 3 & 6 & 6 \\
\hline
\end{tabular}

Figure 10. Analysis results of Pareto fronts according to different uncertainty levels.

(a) Optimistic expectation

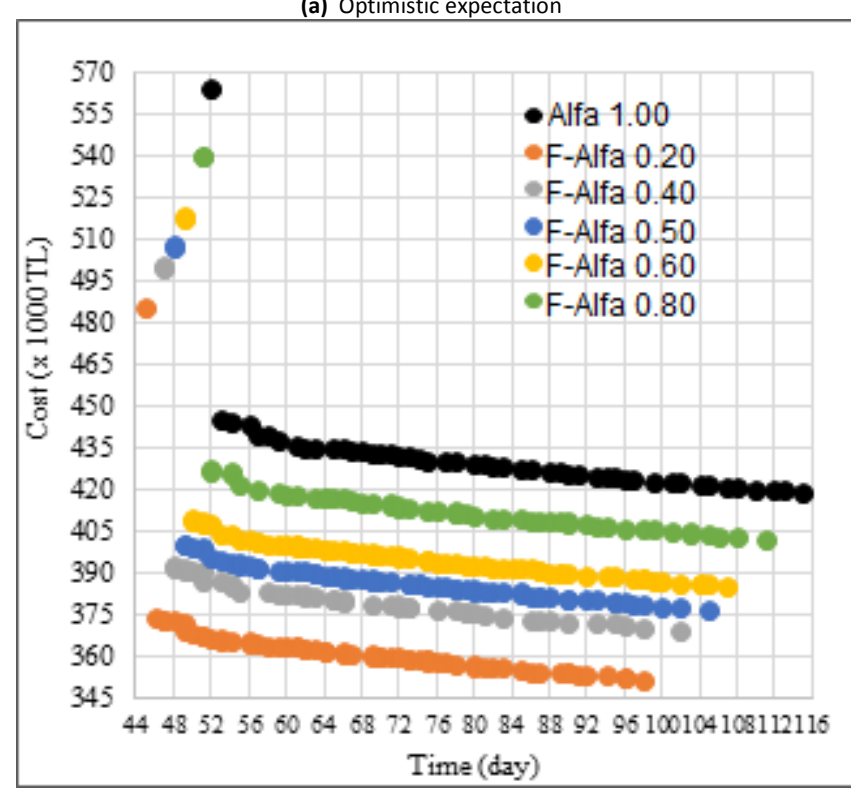

(b) Pessimistic expectation

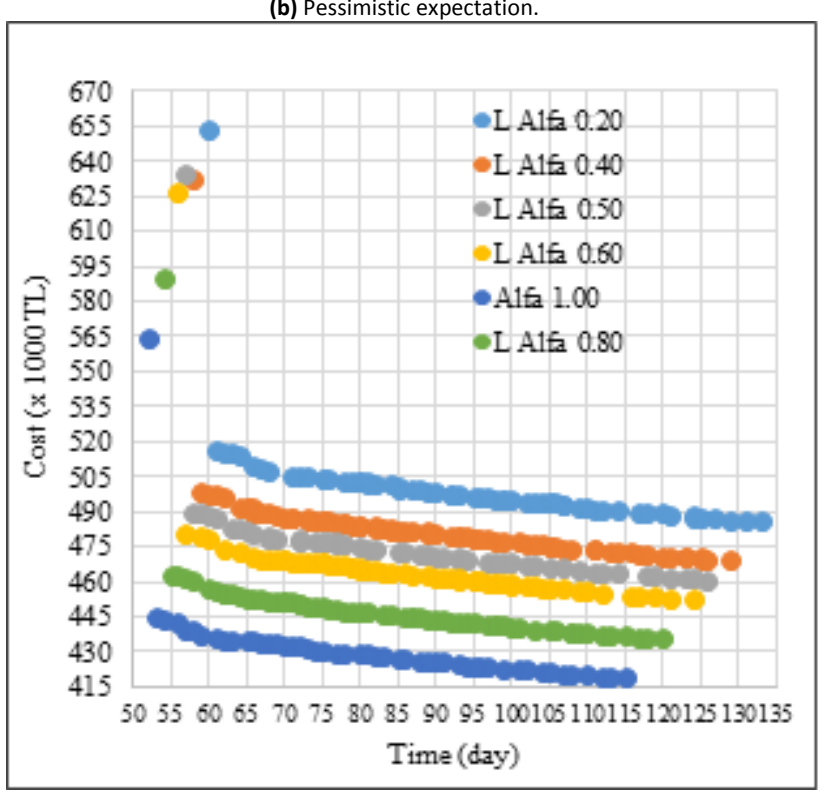

When the results of the pessimistic approach given in Figure 10(b) are examined, pessimistic results remained above the normal result curve. Thus the cost and duration were higher than the optimistic results. Costs tend to decrease when the level of alpha cuts decreases, and the risk level increases. In this respect, the pessimistic approach shows that the project can be completed at a higher cost with a longer perioding different level compared to $\alpha=$ one situation 
(Figure 11). In the optimistic approach, the cost of the project has decreased in the other alpha cutting levels according to the $\alpha=1$ situation.

When the project duration is fixed, the cost change is in an upward trend as the alpha cut level increases in the optimistic region, and the alpha cut level decreases in the pessimistic region. When the $\alpha=1$ level is considered, it is seen that the optimistic costs are low and the pessimistic costs are high. With the proposed model, it was concluded that the cost and duration of the project would decrease as the risk level of the project increases.

Figure 11. Time-cost comparison from Analysis results at different alpha cutting levels.

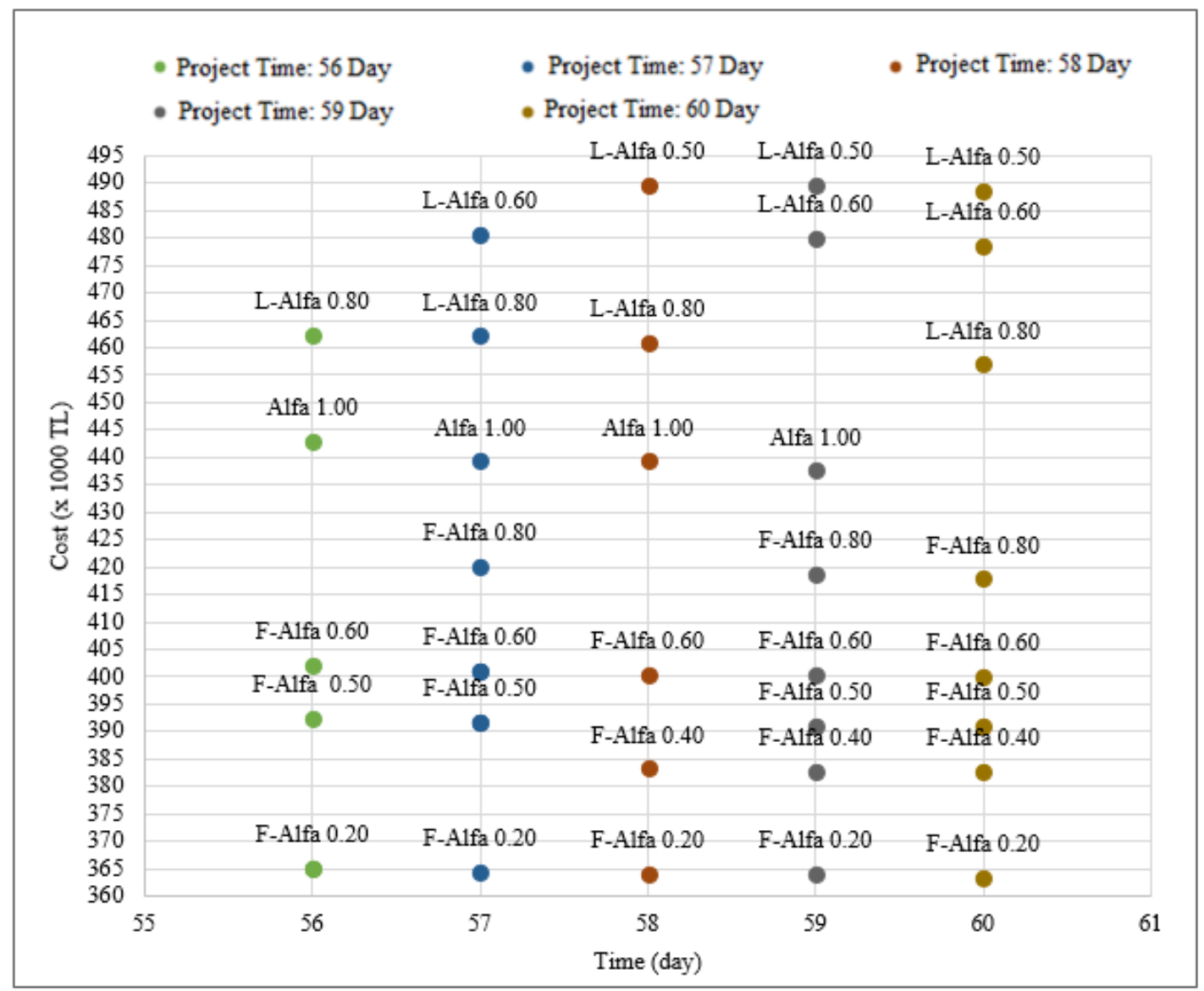

Research Limitations

In this research, both fuzzy logic and genetic algorithms are used to obtain optimum results for optimistic and pessimistic cases. Before the starting of the analysis, an expert opinion is needed to generate the fuzzy sets to model uncertainty. The main point is the complete analysis is depending on an expert opinion, which could be considered as subjective reasoning. And for this point, different analyses may result in different results.

\section{Conclusions}

In this study, a time-cost trade-off model was developed by using the genetic algorithm and fuzzy set theory under uncertainty conditions for construction projects. In this direction, different construction techniques of activities were determined in a building construction project. Each construction technique was evaluated in terms of time and cost at different risk levels of the project. Then, the most appropriate time-cost pairs were obtained by using the genetic algorithm optimization model and Pareto technique.

In the developed model, non-statistical uncertainties in time and cost were evaluated by using the fuzzy set theory. The proposed approach presents different Pareto solutions, including new effective solutions and different schedules, based on the acceptable risk level. The optimum Pareto solutions offered at different risk levels help project managers to choose the risk level and the appropriate options of activities. The desired solution set can be used according to the risk level determined by the project manager. Also, the components in the solution set can be modified, and the model may be re-analyzed. The project manager can use his/her own set of solutions according to the risk level he/she chooses and 
will be able to create scenarios and review the project objectives according to different situations. The most basic tasks of engineering are the provision of efficiency in the construction works in the environment where the needs are high and the resources are limited, and the uncertainties are high. In this study, time-cost optimization was made by taking into consideration the uncertainty and risk factors. With this optimization, it will be possible to make more realistic predictions about the time and cost in the planning stage and to achieve the goals under construction.

Acar Yıldırım, H. (2018). Time cost optimization model with genetic algorithm and fuzzy logic approach in construction project. (Master's thesis). Retrieved from Turkey Council of Higher Education Thesis Center Database. (Accession No. 533052). https://tez.yok.gov.tr/UlusalTezMerkezi/TezGoster?key=as2oTjW5jfr9IKSvmCdJYvK0Quq60lb_uEko4EWQCsPzDTvy0Y2g4TtUAasDQILi

Agdas, D., Warne, D. J., Osio-Norgaard, J., \& Masters, F. J. (2017). Utility of Genetic Algorithms for Solving Large-Scale Construction Time-Cost TradeOff Problems. American Society of Civil Engineers, 32(1), 1-10. https://doi.org/10.1061/(ASCE)CP.1943-5487.0000718

Akcay, C. (2003). Fuzzy logic application samples in civil engineering. (Master's thesis). Retrieved from Turkey Council of Higher Education Thesis Center Database. (Accession No. 130788).

Aly, W. M. (2016). A New Approach for Classifier Model Selection and Tuning Using Logistic Regression and Genetic Algorithms. Arabian Journal for Science and Engineering, 41(12), 5195-5204. https://doi.org/10.1007/s13369-016-2223-2

Aminbakhsh, S., Sönmez, R., \& Bilir, M. (2016). Tamsayılı Doğrusal Programlama Yöntemiyle Kesikli Zaman-Maliyet Ödünleşim Probleminin Optimal Pareto Çözümü [Optimal pareto solution of discrete time-cost trade-off problem with integer linear programming method]. 4th Project and Construction Management Congress, 281-292. Eskisehir, Turkey.

Biswasa, S. K., Karmakera, C. L., \& Biswasa, T. K. (2016). Time-Cost Trade-Off Analysis in a Construction Project Problem : Case Study. International Journal of Computational Engineering Research (IJCER), 06(10), 32-38.

Butcher, W. S. (1967). Dynamic programming for project cost-time curves. Journal of the Construction Division, 93(1), 59-74.

Chanas, S., \& Kamburowski, J. (1981). The use of fuzzy variables in PERT. Fuzzy Sets and Systems, 5(1), 11-19.

Chua, D. K. H., Chan, W. T., \& Govindan, K. (1997). A time-cost trade-off model with resource consideration using genetic algorithm. Civil Engineering Systems, 14(4), 291-311. https://doi.org/10.1080/02630259708970224

Deb, K., Pratap, A., Agarwal, S., \& T. Meyarivan. (2002). A fast and elitist multiobjective genetic algorithm: NSGA-II. IEEE Transactions on Evolutionary Computation, 6(2), 182-197. https://doi.org/10.1109/4235.996017

Diaz, C. F., \& Hadipriono, F. C. (1993). Nondeterministic networking methods, 119(1), 40-57.

Elmas, Ç. (2007). Yapay zeka uygulamaları: yapay sinir ağı, bulanık mantık, genetik algoritma [Applications of artificial intelligence: artificial neural network, fuzzy logic, genetic algorithm]. Istanbul: Seçkin Yayıncılık.

Eshtehardian, E., Afshar, A., \& Abbasnia, R. (2009). Automation in Construction Fuzzy-based MOGA approach to stochastic time - cost trade-off problem. Automation in Construction, 18(5), 692-701. https://doi.org/10.1016/j.autcon.2009.02.001

Feng, C. W., Liu, L., \& Burns, S. A. (1997). Using genetic algorithms to solve construction time-cost trade-off problems. Journal of Computing in Civil Engineering, 11(3), 184-189.

Goldberg David E., \& Holland, J. H. (1988). Genetic algorithms in search, optimization and machine learning (2nd ed.). Canada: Addison-Wesley Publishing Company, Inc.

Habibia, F., Birganib, O. T., Koppelaarc, H., \& Radenovićd, S. (2018). Using fuzzy logic to improve the project time and cost estimation based on Project Evaluation and Review Technique (PERT). Journal of Project Management, 3(4), 183-196. https://doi.org/10.5267/j.jpm.2018.4.002

Haque, K. M. A., \& Hasin, M. A. A. (2012). Genetic algorithm for project time-cost optimization in fuzzy environment. Journal of Industrial Engineering and Management (JIEM), 5(2), 364-381. Retrieved from http://dx.doi.org/10.3926/jiem.410

Hosseini-Nasab, H., Pourkheradmand, M., \& Shahsavaripour, N. (2017). Solving Multi-Mode Time-Cost-Quality Trade-off Problem in Uncertainty Condition Using a Novel Genetic Algorithm. International Journal of Management and Fuzzy Systems, 3(3), 32-40. https://doi.org/10.11648/j.ijmfs.20170303.11

Jebaseeli, M. E., \& Dhayabaran, D. P. (2012). A Direct Approach to Fuzzy Time Cost Trade Off. International Journal of Fuzzy Mathematics and Systems, 2(4), 415-421.

Klir, G. J., \& Yuan, B. (1995). Fuzzy Sets and Fuzzy Logic-Theory and Applications. UK: Upper Saddle River.

Leu, S.-S., Chen, A.-T., \& Yang, C.-H. (2001). A GA-based fuzzy optimal model for construction time-cost trade-off. International Journal of Project Management, 19(1), 47-58.

M. Sorrentino. (2013). Genetic Algorithms for construction time-cost-quality trade-off: A road project case study. In Bo-Ricerche e Progetti per il Territorio la Citta el Architettura, 4(2), 163-176.

McCahon, C. S. (1993). Using PERT as an Approximation of Fuzzy Project-Network Analysis. IEEE Transactions on Engineering Management, 4O(2), 146-153. 
Meyer, W. L., \& Shaffer, L. R. (1965). Extending CPM for multiform project time-cost curves. Journal of the Construction Division, 91(1), 45-68.

Mori, M., \& Tseng, C. C. (1997). A genetic algorithm for multi-mode resource constrained project scheduling problem. European Journal of Operational Research, 100(1), 134-141. https://doi.org/10.1109/JSEE.2014.00071

Paksoy, S., \& Uzun, A. (2015). Genetik algoritma ile kaynak kısıtlı proje çizelgeleme [Resource constrained project scheduling with genetic algorithm]. Cukuruva University Institute of Social Sciences Journal, 17(2), 345-362.

Sen, Z. (2009). Bulanık mantık ilkeleri ve modelleme [Fuzzy logic principles and modeling] (3rd ed.). Istanbul: Su vakfi.

Sonmez, R., \& Halis, Ö. B. (2012). A hybrid genetic algorithm for the discrete time - cost trade-off problem. Expert Systems With Applications, 39(13), 11428-11434. https://doi.org/10.1016/j.eswa.2012.04.019

Talbot, F. B. (1982). Resource-constrained project scheduling with time-resource tradeoffs: The nonpreemptive case. Management Science, 28(10), 1197-1210.

Zalmai, M. L., Akcay, C., \& Manisali, E. (2019). Time-cost optimization using harmony search algorithm in construction projects. Revista de la Construcción, 18(2), 226-237. https://doi.org/10.7764/RDLC.18.2.226 